\title{
ПОПУЛЯЦІЙНО-ГЕНЕТИЧНІ ПАРАМЕТРИ ВІДБОРУ ЗАВОДСЬКИХ РОДИН ВОЛИНСЬКОЇ М'ЯСНОЇ ХУДОБИ
}

\author{
Почукалін Антон Євгенович \\ кандидат сільськогосподарських наук, старший науковвий співробітник \\ Інститут розведення і генетики тварин ім. М.В. Зубця НААН України \\ ORCID: https://orcid.org/0000-0003-2280-5371 \\ Email: pochuk.a@ukr.net
}

Розвиток і перспективність використання у виробництві спеціалізованої породи пов'язаний з чітко окресленими параметрами структурних її формувань (заводських типів, ліній, родин), які постійно знаходяться у русі $і$ змінюють породу в бажаному напряму. Тому завданням зазначеної статmі $\epsilon$ аналіз популяційно-генетичних параметрів відбору у заводських родинах. Матеріалом дослідження були тварини волинської м'ясної породи великої рогатої худоби м'ясного напряму продуктивності, які належать племінному заводу ТОВ «Зоря» Ковельського району Волинської області. Сфоормовано вісімнадиять заводських родин, які розподілені по три у шести лініях зі загальним поголів'ям 160 корів та 13 бугаїв-плідників. Основними параметрами, які були включені у дослідження були - фенотипові мінливість і кореляція, успадковуваність та сила впливу. Успадковуваність визначали методом подвоєного коефіцієнту кореляції «мати-дочка», тоді як силу впливу через співвідношення факторіальної дисперсії до загальної.

Максимальне і мінімальне значення живої маси телиць заводських родин у віці 7, 12, 15 та 18 міс. становить відповідно 183 ке ... 197 ке, 283 ке ... 305 ке, 342 к2 ... 357 к2, 390 к2 ... 415 к2. За коефріцієнта варіації у зазначених вище вікових періодах телиць отриманий низький ступінь мінливості, який не перевищує 8\%. У родинах Буланої 943 (7 міс.), Гарної 536 (12 міс.), Казки 433 (15 міс.) та Корони 2382 (18 міс.) отримані значення середнього ступеня мінливості. Найвище значення середньодобових приростів телищь отримано від наступних родин: Верби 1536 (0-7 міс. - 810 21 21,3 г), Пальми 275 (7-12 міс. - $766 \pm$ 47,7 г), Вісли 1016 (12-15 міс. - $703 \pm$ 22,8 г) та Корони 2382 (15-18 міс. - 802 \pm 106,7 г). Мінливість середньодобових приростів телиць коливається від 8,2\% у період 7-18 міс. до 38,5\% у період від 15-18 міс.

Кореляційний зв'язок між живою масою і молочністю корів та проміром висоти в холиі, тривалістю використання і бальною оцінкою був додатним. Від 72\% до 83\% заводських родин між висотою в холиі та живою масою повновікових корів, молочністю був низький. Слід відмітити заводські родини Корони 2382, Верби 1536 (висота в холиі-молочність), Калини 212 (жива маса корів-тривалість використання), Розетки 1313, Вісли 1016 (бальна оцінка екстер'єру- жива маса корів). Щодо сили впливу, то неістотно впливають на селекційні ознаки лінії матері і батька (1-9\%) порівняно з впливом матерів і батьків (52-90\%).

Поставлена проблема розв'язання раніше не вирішених питань, щодо оиінки заводських родин за господарськи корисними ознаками, а також їх популяційно-генетичні параметри дає змогу аналізувати і проводити селекційну роботу не тільки з лініями, але й заводськими родинами.

Ключові слова: порода, заводські родини, селекційні ознаки, відбір, мінливість, кореляція, сила впливу.

DOI: https://doi.org/10.32845/bsnau.Ivst.2019.4.10

Організація внутрішньопородної структури породи $\epsilon$ основним елементом перспективності поширення породи. Саме вдосконалення господарськи корисних ознак тварин окремих популяцій (внутрішньопородних і заводських типів, ліній та родин) вирішує питання по-перше - реалізації генетичного потенціалу основних селекційних ознак, по-друге надає широкі межі для відбору і підбору кращих представників. Якщо зі заводськими лініями селекційно-племінна робота (моніторинг та оцінка) налагоджені, то заводські родини і досі перебувають у статусі стадних популяцій, а робота з ними проводиться тоді, коли спадковий матеріал жіночих особин на жаль втрачений.

Кожна з представлених в Україні молочних і м'ясних порід великої рогатої худоби має власну внутрішньопорідну структуру, яка підтримує сталий розвиток господарськи корисних ознак. Збільшення їх рівня не можливе без постійного моніторингу популяційно-генетичних параметрів. Використовуючи отриману інформацію формуються селекційні програми реалізація яких безпосередньо впливає на стан породи в цілому та перспективність її використання у подальшому. Популяційно-генетичні параметри (мінливість, кореляція, успадковуваність, дисперсія) відмічені у багатьох дослідженнях, адже за допомогою їх можна з впевненістю оцінити силу впливу генотипових і паратипових факторів на

реалізацію продуктивних ознак худоби [1-11].

Розв'язання раніше не вирішених питань, щодо оцінки заводських родин за господарськи корисними ознаками, а також їх популяційно-генетичні параметри дає змогу аналізувати і проводити селекційну роботу не тільки з лініями, але й заводськими родинами.

Матеріали та методи досліджень. Дослідження проведені на тваринах волинської м'ясної породи великої рогатої худоби, які належать племінному заводу ТОВ «Зоря» Ковельського району Волинської області. Сформовано 18 заводських родин шести ліній, поголів'я нараховує 173 голови. До аналізу популяційно-генетичних параметрів відбору були включені: френотипова мінливість, кореляція та успадковуваність, а також сила впливу. Успадковуваність господарських ознак визначали як подвоєний коефіцієнт кореляції за методом «мати-дочка» $\left(h^{2}=2 \mathrm{rM}-Д\right)$. Силу впливу різних чинників на ефективність формування селекційних ознак визначали методом однофакторного дисперсійного аналізу через співвідношення факторіальної дисперсії до загальної.

Отримані аналітичні дані оброблялися біометрично за загально прийнятими формулами з використанням програмного додатку Microsoft Excel 3 програмного пакету Microsoft Office 2003.

Вісник Сумського національного аграрного університету 
Методикою передбачалось встановити значення запропонованих популяційних параметрів відбору основних селекційних ознак м'ясної худоби - живої маси телиць, корів та бугаїв-плідників у різні вікові періоди, екстер'єру за інструментальною та бальною оцінкою, тривалістю господарського використання та молочністю корів.

Результати досліджень. За впливу численних факторів середовища і спадковості відбувається постійно відхилення значень селекційних ознак від середнього. Така закономірність забезпечує широкі межі для відбору кращих та їх залучення у селекційний процес. Середнє значення та норма оцінки живої маси дослідженої популяції заводських родин у віці $7,12,15$ та 18 міс. становить відповідно $189 \pm 1,1$ кг $\quad(183$ кг... 197 кг $), \quad 293 \pm 1,4$ кг $\quad$ (283 ... 305), $348 \pm 1,6$ кг $(342 \ldots 357)$ та $401 \pm 1,4$ кг $\quad(390 \ldots 415)$. За величиною фенотипової мінливості (C.V.) живої маси телиць отримані значення з низьким ступенем, які не перевищують 8\%. Відмічено спад коефріцієнта варіації з 7,4\% у телиць 7 міс. до 4,4\% у віці 18 міс. Крім того у телиць віком 7 міс. заводських родин Акули 102 (C.V. - 9,8\%), Арфи 599 $(10,1 \%)$, Буланої $943(10,4 \%)$, Гарної 536 (8,8\%) та Десни 870 (8,7\%); 12 міс. - Гарної 536 (12,6\%), Казки 433 (9\%), Смородини 613 (9,2\%); 15 міс. - Казки 433 (13,5\%); 18 міс. Корони $2382(10,1 \%)$ отримані значення середнього ступеня мінливості.

Зміна живої маси тварин в динаміці має важливе значення, оскільки є базовим показником інтенсивності росту. Найбільше значення середньодобових приростів телиць у період від народження до 7 міс. (765 \pm 5,2 г). Надалі, спостерігається поступове зменшення з кожним наступним періодом: 7-12 міс. (691 $\pm 7,7$ г), 12-15 міс. (633 \pm 14,7 г), 15-18 міс. (560 $\pm 17,0$ г). Крім того, найвищими значеннями середньодобових приростів у вікові періоди відзначаються наступні заводські родини: від народження до 7 міс. - телиці родини Верби 1536 (810 \pm 21,3 г), 7-12 міс. Пальми 275 (766 $\pm 47,7$ г), 12-15 міс. - Вісли 1016 $(703 \pm 22,8)$ та $15-18$ міс. - телиці родини Корони 2382 $(802 \pm 106,7$ г). Мінливість значень середньодобових приростів у заводських родинах має середній ступінь у періоди від народження до 7 міс. $(8,6 \%), 7-12$ міс. $(14,1 \%)$ та 7 18 міс. $(8,2 \%)$ та високий у періоди між $12-15$ міс. $(29,4 \%)$ та $15-18$ міс. $(38,5 \%)$.

За живою масою повновікових корів відмічено низький рівень мінливості, який знаходиться на рівні $2,5 \ldots 4,6 \%$. Середнє значення живої маси повновікових корів становить 584 кг 3 максимальною величиною зазначеної ознаки 640 кг у родині Смородини 613, а мінімальною у 543 кг у представниці родини Пальми 275 та Розетки 1313. Також, слід відмітити, що у 15 родинах максимальне значення живої маси повновікових корів становить понад 600 кг, що $є$ особливо цінним матеріалом для відбору кращих і залучення у селекційно-племінну роботу. У поколіннях заводських родин спостерігається незначне $(1,5 \%)$ збільшення коефіцієнта мінливості від родоначальниці (2,3\%) до III покоління $(3,8 \%)$ хоча і має низький ступінь.

За отеленнями крайні межі коефіцієнтів варіації молочності корів становлять: після І отелення - від 2,1\% (ро- дина Гарної 536) до 8,7\% (родина Акули 102); після II отелення від 2,4\% (Гарної 536) до 8,4\% (Казки 433) і після III отелення від 4,1\% (Галки 37) до 8,6\% (родина Вісли 1016). За показниками максимального значення молочності корів середній рівень у заводських родинах становить $209 \pm 0,71$ кг з крайніми відхиленнями у родинах Галки 37 $(200 \pm 1,89$ кг) та Верби 1536 (216 $\pm 3,24$ кг) за $\mathrm{P}<0,1$.

Проміри повновікових корів також мають низький ступінь мінливості, який не перевищує $7 \%$. За висотними промірами корів значення коливають від 2,3 до 2,5\%, а за широтними $-5,4 \ldots 7,0 \%$.

За показниками відтворної здатності відмічено чітку диференціацію середніх значень у заводських родинах. Так, крайні значення міжотельного періоду та коефріцієнту відтворної здатності становлять відповідно від 346,7 днів (родина Розетки 1313) до 432,9 днів (Галки 421) та від 0,843 (Галка 421) до 1,05 (Розетки 1313). За тривалістю використання у стаді слід відмітити родини Розетки 1313, Пальми 275, Смородини 613, Казки 433, Гарної 536, Калини 212, Верби 1536, Акули 102 значення яких перевищує 6 отелень.

У бугаїв-плідників, які віднесені до заводських родин за живою масою у віці 7, 12, 15, 18 міс., 3 років та промірами статей тіла у віці 3 років отримані низькі ступені мінливості, які не перевищують C.V. $=6,4 \%$.

Кореляційний зв'язок між селекційними ознаками корів заводських родин в усіх випадках був додатним. Між висотою в холці та живою масою повновікових корів і молочністю у $83 \%$ та $72 \%$ відповідно низький. У родинах Галки 1537, Веселки 444 та Пальми 275 між проміром висоти в холці та живою масою - високий з межами від 0,540 до 0,969. У двох родинах (Корони 2382 та Верби 1536) встановлений високий зв'язок між висотою в холці та молочністю корів.

Середній кореляційний зв'язок отриманий між живою масою повновікових корів та тривалістю використання у 5 заводських родинах, з максимальним значенням у родині Корони 2382 ( $r=+0,496)$. У 12 родинах встановлений низький зв'язок між молочністю за I та III отелення і лише у двох (Калини 212, Верби 1536) - високий.

Між екстер'єрною оцінкою в балах та живою масою повновікових корів у 4 заводських родинах отриманий високий зв'язок, значення яких коливається в межах від 0,632 у родині Розетки 1313 до 0,734 у родині Вісли 1016. В той час отриманий низький кореляційний зв'язок між бальною оцінкою за екстер'єр та молочністю корів, який спостерігається у $89 \%$ досліджуваних родин.

Також встановлений середній зв'язок між різними віковими періодами у бугаїв-плідників, які віднесені до заводських родин. Так у період 7-12 міс. зв'язок становив $r=+0,432,12-15$ міс. $-r=+0,396,15-18$ міс. $-r=+0,456$ та 715 мic. $-r=+0,322$.

Коефіцієнт успадковуваності за живою масою у різні вікові періоди і молочністю корів - низький і не перевищує 0,110. Сила однофракторного дисперсійного впливу батьків не однаково впливає на продуктивні якості нащадків. Встановлено (табл.) високий вплив матері і батька на молочність за III отелення та живу масу у віці 210 днів та 18 місяців. 
1. Сила впливу батьків на різні показники продуктивності

\begin{tabular}{|c|c|c|c|c|c|}
\hline \multirow{3}{*}{ Вплив } & \multicolumn{5}{|c|}{ Показники продуктивності, кГ } \\
\hline & \multicolumn{3}{|c|}{ Молочність у віці 210 днів } & \multicolumn{2}{|c|}{ Жива маса } \\
\hline & І отелення & ІІ отелення & III отелення & 210 днів & 18 місяців \\
\hline Батька & $0,52 \pm 0,818$ & $0,86 \pm 0,280^{1}$ & $0,57 \pm 0,683$ & $0,54 \pm 0,793$ & $0,62 \pm 0,681^{2}$ \\
\hline Матері & $0,71 \pm 0,743^{1}$ & $0,90 \pm 0,272^{1}$ & $0,69 \pm 0,780$ & $0,71 \pm 0,746^{1}$ & $0,61 \pm 0,952$ \\
\hline Лінії батька & $0,02 \pm 0,004$ & $0,04 \pm 0,044$ & $0,06 \pm 0,049$ & $0,05 \pm 0,043$ & $0,09 \pm 0,043^{2}$ \\
\hline Лінії матері & $0,09 \pm 0,035^{1}$ & $0,06 \pm 0,037$ & $0,03 \pm 0,043$ & $0,03 \pm 0,036$ & $0,01 \pm 0,036$ \\
\hline
\end{tabular}

Примітка: ${ }^{1}-P<0,05$.

Найбільш істотно впливає мати на молочність корів за II отелення та живу масу телиць у 18 місяців, а батько на живу масу телиць у віці 210 днів. Від 1 до 9\% знаходиться вплив ліній обох батьків.

Висновки. Популяційно-генетичні параметри заводських родин волинської м'ясної породи великої рогатої худоби мають свою специффіку, яку потрібно враховувати у

селекційних програмах щодо удосконалення породи та планах племінної роботи зі стадами. Відмічений, у більшості випадків, невисокий ступінь мінливості, успадковуваності, зв'язок кореляції за основними селекційними ознаками. Сила впливу батьків суттєво впливає на основні показники продуктивності, тоді як влив ліній неістотний.

\section{Список використаної літератури:}

1. Бабік Н. П. Тривалість та ефективність довічного використання корів голштинської породи залежно від селекційних індексів їх предків. Вісник Сумського національного аграрного університету. Сер. Тваринництва. 2017. Вип. 5/1 (31). С. 1621.

2. Вдовиченко Ю. В., Фурса Н. М. Продуктивність та відтворювальні якості тварин сірої української породи великої рогатої худоби асканійської селекції. Науковий вісник «Асканія-Нова». 2017. Вип. 10. С. 157-166.

3. Гуменний В. Збереження генофонду сірої української породи при внутрішньопородній селекції. Тваринництво України. 2010. № 9. С. 13-17.

4. Гуменний В. Д. Внутрішньопородна селекція при збереженні генофонду сірої української породи. Розведення і генетика тварин. 2009. Вип. 43. - С. 108-113.

5. Лепехина Т. В., Бакай А. В., Бакай Ф. Р. Изменчивость и повторяемость признаков молочной продуктивности у коров черно-пестрой породы. Зоотехния. 2018. № 12. С. 10-11.

6. Особливості формування живої маси корів південної м'ясної породи в умовах інтенсивного теплового навантаження / Ю. В. Вдовиченко, А. В. Писаренко, Н. М. Фурса та ін. Науковий вісник «Асканія-Нова». 2018. Вип. 11.С. 55-62.

7. Полупан Ю. П. Генетична детермінація тривалості та ефективності довічного використання чорно-рябої молочної худоби. Розведення і генетика тварин. 2015. Вип. 49. - С. 120-133.

8. Полупан Ю. П., Сіряк В. А. Вплив інтенсивності формування на живу масу телиць і молочну продуктивність корів. Розведення і генетика тварин. 2019. Вип. 57. С. 111-125. doi: 10.31073/abg.57.14

9. ФурсаН.․․ Рівень відтворювання та плодючості маток асканійської популяції сірої української породи великої рогатої худоби. Науковий вісник «Асканія-Нова». 2018. Вип. 11. С. 143-156.

10. Хмельничий Л. М., Вечорка В. В. Сполучена мінливість промірів та індексів будови тіла з надоєм корів української чорно-рябої молочної породи. Розведення і генетика тварин. 2015. Вип. 50. С. 96-102.

11. Reznikova Yu. M. Comparative characteristics of Ukrainian grey cattle and some specialized beef breeds by economically valuable traits. Розведення і генетика тварин. 2016. Вип. 52. С. 221-227.

\section{References:}

1. Babik, N.P., 2017. Tryvalist' ta efektyvnist' dovichnoho vykorystannya koriv holshtyns'koyi porody zalezhno vid selektsiynykh indeksiv yikh predkiv [Duration and efficiency of lifelong use of Holstein cows depending on breeding indices of their ancestors]. Visnyk Sums'koho natsional'noho ahrarnoho universytetu. Seriya Tvarynnytstva, issue 5/1(31), pp. 16-21.

2. Vdovychenko, Yu.V. and Fursa N.M., 2017. Produktyvnist' ta vidtvoryuval'ni yakosti tvaryn siroyi ukrayins'koyi porody velykoyi rohatoyi khudoby askaniys'koyi selektsiyi [Productivity and reproductive quality of animals of the Gray Ukrainian cattle of Ascanian breeding]. Naukovyy visnyk «Askaniya-Nova», issue 10, pp. 157-166.

3. Humennyy, V., 2010. Zberezhennya henofondu siroyi ukrayins'koyi porody pry vnutrishn'oporodniy selektsiyi [Conservation of the gene pool of the Gray Ukrainian breed during intra-breeding]. Tvarynnytstvo Ukrayiny, no. 9, pp. 13-17.

4. Humennyy, V.D., 2009. Vnutrishn'oporodna selektsiya pry zberezhenni henofondu siroyi ukrayins'koyi porody [Intrabreeding selection while conservation the gene pool of the Gray Ukrainian breed]. Rozvedennya $i$ henetyka tvaryn, issue 43, pp. 108-113.

5. Lepehina, T.V., Bakaj A.V. and Bakaj F.R., 2018. Izmenchivost i povtoryaemost priznakov molochnoj produktivnosti u korov cherno-pestroj porody [Variability and repeatability milk production traits in cattle black and white breed]. Zootehniya, no. 12, pp. $10-11$.

6. Vdovychenko, Yu.V., Pysarenko A.V., Fursa N.M. and Makarchuk R.M., 2018. Osoblyvosti formuvannya zhyvoyi masy koriv pivdennoyi m"yasnoyi porody v umovakh intensyvnoho teplovoho navantazhennya [Peculiarities of formation of live weight of cows of southern meat breed under conditions of intense heat load]. Naukovyy visnyk «Askaniya-Nova», issue 11, pp. 55-62.

7. Polupan, Yu.P., 2015. Henetychna determinatsiya tryvalosti ta efektyvnosti dovichnoho vykorystannya chorno-ryaboyi molochnoyi khudoby [Genetic determination of the duration and effectiveness of lifetime use of the Black-and-White dairy catlle]. 
Rozvedennya i henetyka tvaryn, issue 49, pp.120-133.

8. Polupan, Yu.P. and Siryak V.A., 2019. Vplyv intensyvnosti formuvannya na zhyvu masu telyts' i molochnu produktyvnist' koriv [Influence of intensity of formation on live weight of heifers and milk productivity of cows]. Rozvedennya i henetyka tvaryn, issue 57, pp. 111-125. doi: 10.31073/abg.57.14

9. Fursa, N.M., 2018. Riven' vidtvoryuvannya ta plodyuchosti matok askaniys'koyi populyatsiyi siroyi ukrayins'koyi porody velykoyi rohatoyi khudoby [Level of reproduction and fertility of uterus of Ascanian population of the Gray Ukrainian breed of cattle]. Naukovyy visnyk «Askaniya-Nova», issue 11, pp. 143-156.

10. Khmel'nychyy, L.M. and Vechorka V.V., 2015. Spoluchena minlyvist' promiriv ta indeksiv budovy tila z nadoyem koriv ukrayins'koyi chorno-ryaboyi molochnoyi porody [Combined variability of measurements and indices of body structure with milk yield of the Ukrainian black-and-white dairy cows]. Rozvedennya i henetyka tvaryn, issue 50, pp. 96-102.

11. Reznikova, Yu.M., 2016. Comparative characteristics of Ukrainian grey cattle and some specialized beef breeds by economically valuable traits. Rozvedennya i henetyka tvaryn. issue 52, pp. 221-227.

\section{Pochukalin A. Ye.}

\section{Population-genetic parameters of selection of local families of volinian beef cattle}

The development and promising use in the production of specialized breed is associated with clearly defined parameters of its structural formations (local types, lines, families), which are constantly in motion and change the breed in the desired direction. Therefore, the objective of the article is to analyze the population-genetic parameters of selection in local families. The material of the study was animals of the Volinian cattle breed of meat direction of productivity belonging to the breeding plant of LLC «Zorya», Kovel district, Volyn region. Eighteen local families have been formed, divided into three in six lines with a total livestock of 160 cows and 13 breeding bulls. The main parameters included in the study were phenotypic variability and correlation, inheritance and power of influence. Inheritance was determined by the method of doubling the correlation coefficient "mother-daughter", whereas the force of influence due to the ratio of factorial variance to total. The maximum and minimum values of live weight of heifers of local families at the ages of 7, 12, 15 and 18 months are respectively $183 \mathrm{~kg} \ldots 197 \mathrm{~kg}, 283 \mathrm{~kg} \ldots 305 \mathrm{~kg}, 342 \mathrm{~kg} \ldots 357 \mathrm{~kg}, 390 \mathrm{~kg} \ldots 415 \mathrm{~kg}$. The coefficient of variation in the above-mentioned heifers of heifers obtained a low degree of variability not exceeding $8 \%$. In families of Bulana 943 (7 months), Harna 536 (12 months), Kazka 433 (15 months) and Korona 2382 (18 months) received values of average degree of variability. The highest values of average daily growth of heifers were obtained from the following families: Verba 1536 (0-7 months - $810 \pm 21.3 \mathrm{~g}$ ), Palma 275 (7-12 months - $766 \pm 47.7 \mathrm{~g})$, Visla 1016 (12-15 months - $703 \pm 22,8 \mathrm{~g})$ and Korona 2382 (15-18 months - $802 \pm 106,7 \mathrm{~g}$ ). The variability in daily calf growth ranges from $8,2 \%$ in the period $7-18$ months to $38,5 \%$ in the period from 15-18 months. The correlation between live weight and milkiness of cows and height measurement in the withers, duration of use and score was in all cases positive. From $72 \%$ to $83 \%$ of local families between the height at the withers and the live weight of fullgrown cows, milkiness was low. It should be noted the local families of Korona 2382, Verba 1536 (height at the withers-milkweed), Kalyna 212 (live weight of cows-duration of use), Rozetka 1313, Visla 1016 (point estimate of the exterior live weight of cows). Regarding the force of influence, they have no significant effect on the selection traits of the mother and father line (1-9\%) compared with the influence of mothers and fathers (52-90\%). The problem of solving previously unanswered questions regarding the assessment of local families by economic usefulness, as well as their population-genetic parameters, makes it possible to analyze and carry out breeding work not only with lines, but also with local families.

Key words: breed, local families, breeding traits, selection, variability, correlation, force of influence.

Дата надходження до редакції: 07.10.2019 р. 